BIOSFER: JURNAL PENDIDIKAN BIOLOGI (BIOSFERJPB)

2017, volume 10 No 1, 9-16

ISSN: 0853-2451

\title{
PENGARUH GAYA BELAJAR DAVID KOLB (DIVERGER, ASSIMILATOR, CONVERGER, ACCOMMODATOR) TERHADAP HASIL BELAJAR SISWA PADA MATERI PENCEMARAN LINGKUNGAN
}

The Influence of David Kolb's Learning Style (Diverger, Assimilator, Converger, Accommodator) to Students Learning Outcomes in Environmental Pollution

\author{
Eka Putri Azrai, Ernawati' Gita Sulistianingrum \\ Pendidikan Biologi Fakultas MIPA Universitas Negeri Jakarta \\ Email: epazrai@yahoo.com
}

\begin{abstract}
Learning style is a complex way that someone feels most effective and efficient in learning. David Kolb divides learning style into four groups, there are diverger, assimilator, converger, and accommodator. The research aimed to know the influence of David Kolb's learning style (diverger, assimilator, converger, accommodator) to students learning outcomes in Environmental Pollution. This research was conducted at 105 Senior High School of Jakarta on April - May 2016. The method that used in this research was Ex Post Facto with survey technique. The sample determination for each learning styles based on learning style groups that have less number of students. The sample that used for each learning styles was 11 students. Based on this research, these four learning styles have different average learning outcome. Prerequisite test showed that data normally distributed and homogenously. Based on the hypothesis test used one-way ANOVA, known that cognitive, affective, and psychomotor learning outcomes have $\mathrm{F}_{\text {count }}>\mathrm{F}_{\text {table, }}$, so that $\mathrm{H}_{0}$ was rejected on 0,05 significant level. It means there is influence of David Kolb's learning style (diverger, assimilator, converger, accommodator) to students learning outcomes in Environment Pollution.
\end{abstract}

Keywords : accommodator, assimilator, converger, diverger, learning styles, learning outcomes

\section{PENDAHULUAN}

Belajar merupakan suatu proses yang kompleks yang terjadi pada diri setiap manusia sepanjang hidupnya. Dapat dikatakan belajar adalah proses atau usaha yang dilakukan setiap individu untuk memperoleh perubahan tingkah laku baik dalam bentuk pengetahuan, sikap, keterampilan, serta nilai-nilai positif yang didapatkan selama proses pembelajaran. Hal ini sesuai dengan pendapat Susilo (2009) yang menyatakan bahwa inti dari belajar adalah pengalaman, dan dengan bekal pengalaman ini individu pembelajar akan dapat berubah dari 
dimensi tidak tahu menjadi tahu. Implikasi dari proses pembelajaran akan tampak pada tiga tataran domain yaitu kognitif, afektif, dan psikomotorik.

Ada banyak faktor yang berperan dalam menentukan keberhasilan kegiatan belajar siswa. Faktor tersebut dapat berasal dari dalam maupun dari luar diri siswa (Slameto, 2003). Salah satu faktor dominan yang menentukan keberhasilan proses belajar adalah dengan memahami bahwa setiap siswa merupakan individu yang unik dan berbeda satu sama lain. Perbedaan ini dapat terlihat dari gaya belajarnya. Bila keunikan ini dihargai, maka siswa akan dapat mengembangkan diri secara optimal sesuai dengan kemampuan yang dimilikinya.

Gaya belajar merupakan cara-cara yang lebih disukai seseorang dalam melakukan kegiatan berpikir, memproses, dan mengerti suatu informasi. Selain itu, menurut Ghufron dan Risnawita (2012) gaya belajar merupakan cara yang ditempuh oleh masing-masing individu untuk berkonsentrasi pada proses dan menguasai informasi yang baru melalui persepsi yang berbeda. Gaya belajar merepresentasikan karakteristik seseorang terhadap pengalaman yang diinduksinya. Oleh karena itu, mengetahui gaya belajar yang sesuai adalah salah satu kunci keberhasilan seseorang dalam belajar.

Penelitian mengenai gaya belajar diperkirakan telah dimulai pada lima dekade yang lalu (Cassidy, 2004). Berdasarkan hasil dari penelitian-penelitian tersebut dapat diketahui bahwa terdapat beberapa teori dan model mengenai gaya belajar serta faktor-faktor yang mempengaruhinya. Claxton dan Murrel (1987) membagi gaya belajar menjadi empat kelompok besar, yaitu berdasarkan kepribadian, pengolahan informasi, interaksi sosial, dan pilihan pengajaran.

Gaya belajar David Kolb merupakan salah satu model gaya belajar yang berdasarkan pada proses pengolahan informasi. David Kolb menegaskan bahwa orientasi seseorang dalam proses belajar dipengaruhi empat kecenderungan, yaitu concrete experience (feeling), reflective observation (watching), abstract conceptualization (thinking), dan active experimentation (doing). Keempat kecenderungan belajar tersebut bila dikombinasikan akan membentuk empat tipe gaya belajar yaitu gaya belajar diverger, assimilator, converger, dan accommodator (Ghufron dan Risnawati, 2012).

Gaya belajar diyakini berpengaruh terhadap hasil belajar siswa. Sugiyanto (2007) dan Ramlah et al. (2014) membuktikan bahwa terdapat pengaruh gaya belajar Kolb terhadap prestasi akademik siswa. Gaya belajar yang sesuai dengan keadaan siswa memberikan kontribusi terhadap prestasi akademik. Siswa yang belajar dengan gaya belajar yang sesuai akan memperoleh prestasi yang lebih baik.

Materi Pencemaran Lingkungan merupakan salah satu topik pelajaran Biologi pada siswa kelas $\mathrm{X}$ yang menekankan proses pengolahan informasi dan menuntut siswa untuk memiliki kemampuan analisis yang tinggi. Siswa yang memiliki gaya belajar diverger, assimilator, converger, dan accommodator tentunya akan memiliki cara yang berbeda dalam mengolah informasi yang diterimanya. Walaupun memiliki cara yang berbeda dalam mengolah informasi, setiap siswa diharapkan dapat memperoleh hasil belajar yang baik dengan cara memaksimalkan kecenderungan belajar sesuai dengan gaya belajar yang dimilikinya. Penelitian ini dilakukan bertujuan untuk mengetahui pengaruh gaya belajar David Kolb (diverger, assimilator, converger, accommodator) terhadap hasil belajar siswa pada materi Pencemaran Lingkungan. 


\section{METODE PENELITIAN}

Metode penelitian yang digunakan adalah metode Ex Post Facto dengan teknik survei. Variabel bebas (X) dalam penelitian ini adalah gaya belajar David Kolb (diverger, assimilator, converger, accommodator), sedangkan variabel terikatnya $(\mathrm{Y})$ adalah hasil belajar siswa pada materi Pencemaran Lingkungan. Penelitian ini dilaksanakan di SMA Negeri 105 Jakarta, pada bulan April - Mei 2016.

Sampel yang digunakan pada penelitian ini adalah siswa kelas X MIA yang berjumlah 44 siswa. Jumlah sampel untuk tiap gaya belajar ditentukan dari kelompok gaya belajar dengan jumlah siswa yang terkecil, yaitu gaya belajar converger dengan jumlah 11 siswa. Gaya belajar diverger, assimilator dan accommodator yang memiliki jumlah siswa lebih besar akan dipilih secara simple random sampling sebanyak jumlah sampel yang telah ditentukan untuk tiap gaya belajar.

Data gaya belajar diperoleh melalui kuesioner Kolb's Learning Style Inventory (KLSI) Version 3.1. Pada penelitian ini data hasil belajar kognitif diperoleh melalui tes hasil belajar siswa pada materi Pencemaran Lingkungan. Data hasil belajar afektif diperoleh melalui observasi sikap selama pembelajaran. Sedangkan data hasil belajar psikomotorik diperoleh melalui penilaian kinerja saat praktikum.

Data yang berdistribusi normal dan homogen diuji menggunakan ANAVA satu arah dengan taraf signifikansi $\alpha=0,05$ untuk menguji hipotesis. Untuk mencari besar signifikan perbedaan, maka pengujian dilanjutkan dengan uji Least Significant Difference (LSD) dengan taraf signifikansi $\alpha=0,05$ untuk uji satu pihak.

\section{HASIL PENELITIAN}

Berdasarkan hasil penelitian dapat diketahui bahwa terdapat perbedaan rata-rata nilai hasil belajar antara siswa dengan gaya belajar diverger, assimilator, converger, dan accommodator. Perbedaan nilai rata-rata hasil belajar tersebut dapat digambarkan pada diagram batang berikut:

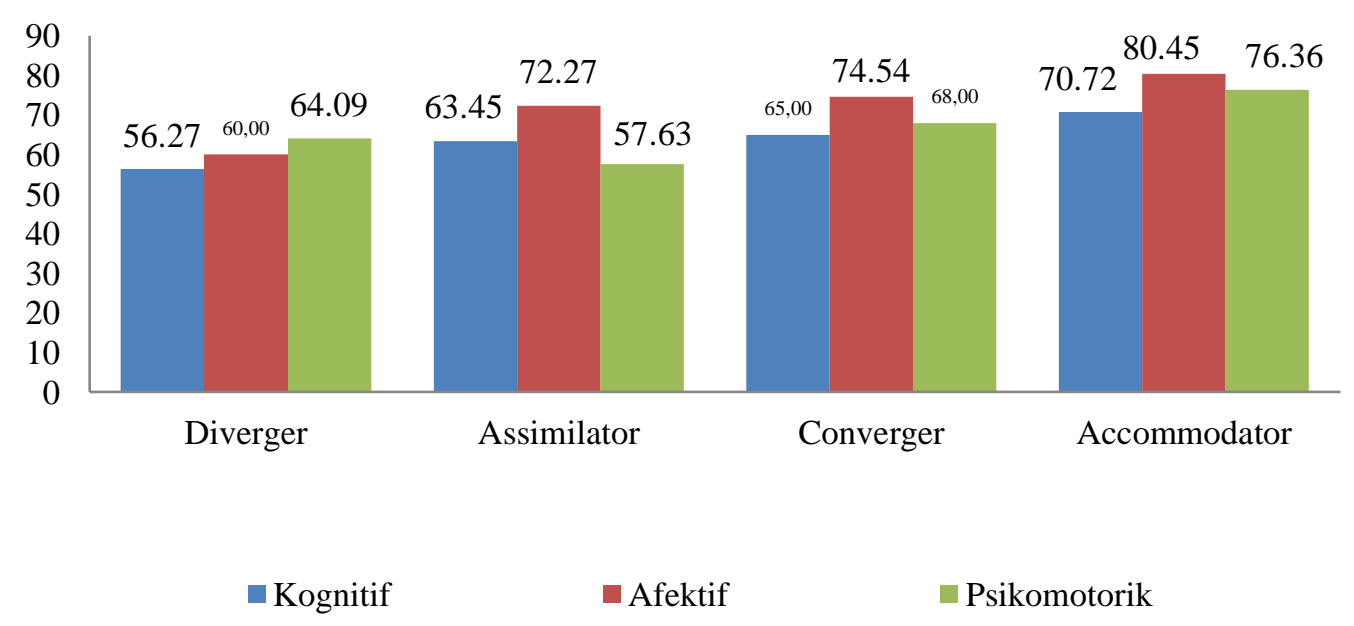

Gambar 1. Perbedaan Nilai Rata-rata Hasil Belajar Siswa dengan Gaya Belajar Diverger, Assimilator, Converger, Accommodator 
Berdasarkan hasil pengujian hipotesis menggunakan ANAVA satu arah, diperoleh $F_{\text {hitung }}>F_{\text {tabel }}$ pada taraf signifikansi $\alpha=0,05$. Maka dari itu tolak $\mathrm{H}_{0}$ yang artinya nilai hasil belajar kognitif, afektif, dan psikomotorik siswa dengan keempat gaya belajar memiliki ratarata yang berbeda

Tabel 1. Perhitungan ANAVA Satu Arah Hasil Belajar Kognitif, Afektif, dan Psikomotorik

\begin{tabular}{lcc}
\hline \multicolumn{1}{c}{ Hasil Belajar } & F $_{\text {hitung }}$ & F $_{\text {tabel }}$ \\
\hline Kognitif & 4,53 & 2,84 \\
Afektif & 3,89 & \\
Psikomotorik & 2,96 & \\
\hline
\end{tabular}

Berdasarkan hasil uji lanjut dengan menggunakan uji Least Significant Difference (LSD) dengan taraf signifikansi $\alpha=0,05$, diketahui bahwa gaya belajar accommodator dan converger berbeda signifikan dengan diverger pada hasil belajar kognitif dan afektif. Selain itu gaya belajar accommodator berbeda signifikan dengan assimilator pada hasil belajar psikomotorik.

Tabel 2. Notasi Hasil Belajar Siswa pada Materi Pencemaran Lingkungan Keterangan : Gaya belajar dengan notasi huruf yang sama tidak berbeda signifikan

\begin{tabular}{lccc}
\hline \multicolumn{1}{c}{ Gaya Belajar } & Kognitif & Afektif & Psikomotorik \\
\hline Diverger & $\mathrm{a}$ & $\mathrm{a}$ & $\mathrm{ab}$ \\
Assimilator & $\mathrm{ab}$ & $\mathrm{ab}$ & $\mathrm{a}$ \\
Converger & $\mathrm{b}$ & $\mathrm{b}$ & $\mathrm{ab}$ \\
Accommodator & $\mathrm{b}$ & $\mathrm{b}$ & $\mathrm{b}$ \\
\hline
\end{tabular}

\section{PEMBAHASAN}

Hasil penelitian ini menunjukan bahwa terdapat pengaruh gaya belajar David Kolb (diverger, assimilator, converger, accommodator) terhadap hasil belajar siswa pada materi Pencemaran Lingkungan. Hal tersebut dapat terlihat dari perbedaan nilai rata-rata hasil belajar siswa baik pada ranah kognitif, afektif, dan psikomotorik. Perbedaan hasil belajar tersebut disebabkan karena tiap siswa memiliki cara yang berbeda-beda dalam menerima dan mengolah informasi selama proses belajar.

Berdasarkan data hasil belajar dapat diketahui bahwa gaya belajar accommodator unggul pada hasil belajar ranah kognitif, afektif, dan psikomotorik. Hal tersebut dapat dilihat dari nilai rata-rata siswa dengan gaya accommodator yang paling tinggi dibandingkan ketiga gaya belajar lainnya. Selain itu siswa dengan gaya belajar accommodator lebih banyak memiliki nilai yang berkriteria baik dan sangat baik pada hasil belajar kognitif, afektif, dan psikomotorik.

Gaya belajar accommodator merupakan kombinasi antara kutub kecenderungan active experimentation (doing) dan concrete experience (feeling). Dalam pembelajaran materi Pencemaran Lingkungan, siswa dengan gaya belajar accommodator memiliki kemampuan belajar yang baik dari hasil pengalaman nyata yang dilakukannya sendiri (Susilo, 2009). Gaya belajar accommodator kurang mengedepankan daya analisa seperti 
yang dituntut dalam materi Pencemaran Lingkungan. Siswa dengan gaya belajar accommodator lebih banyak belajar dari pengalaman nyata dalam menghadapi berbagai masalah pencemaran yang terjadi di lingkungan sekitarnya. Selain itu dalam memecahkan masalah, siswa dengan gaya belajar accommodator biasanya mempertimbangkan faktor manusia untuk mendapatkan masukan atau informasi (Ghufron dan Risnawita, 2012). Siswa akan memilih cara bertukar pikiran dengan orang-orang sekitarnya (guru atau teman) untuk memecahkan masalah. Hal itu yang dapat menyebabkan gaya belajar accommodator memiliki rata-rata hasil belajar kognitif yang tinggi.

Siswa dengan gaya belajar accommodator juga memiliki nilai rata-rata hasil belajar afektif yang tertinggi dibandingkan ketiga gaya belajar lainnya. Kutub kecenderungan active experimentation (doing) yang ada dalam diri siswa dengan gaya belajar accommodator, membuat siswa tersebut aktif selama proses pembelajaran. Siswa dengan gaya belajar accommodator cenderung untuk bertindak berdasarkan intuisi atau dorongan hati (Susilo, 2009). Selain itu, sifatnya yang terbuka membuat siswa dengan gaya belajar accommodator mampu menghargai pendapat orang lain ketika terjadi perbedaan pendapat.

Selain itu siswa dengan gaya belajar accommodator juga memiliki nilai rata-rata hasil belajar psikomotorik yang tertinggi dibandingkan ketiga gaya belajar lainnya. Dibandingkan dengan gaya belajar diverger, assimilator, dan converger, gaya belajar accommodator lebih unggul dalam melakukan eksperimen (Indriana, 2011). Selain itu siswa dengan gaya belajar accommodator suka membuat rencana dan melibatkan dirinya dalam berbagai pengalaman baru dan menantang. Praktikum penjernihan air pada penelitian ini dapat dikatakan sebuah pengalaman yang baru dan menantang karena sebelumnya tidak pernah dilakukan praktikum selama pembelajaran Biologi. Oleh karena itu, ketika praktikum ini dilakukan siswa dengan gaya belajar accommodator sangat tertarik dan terampil dalam melakukan praktikum.

Hasil dalam penelitian ini sesuai dengan penelitian yang telah dilakukan oleh Wijayanti (2011). Penelitian tersebut membuktikan bahwa terdapat perbedaan hasil belajar kognitif berdasarkan ragam gaya belajar menurut David Kolb pada pembelajaran dengan metode praktikum. Pada penelitian tersebut gaya belajar accommodator juga memiliki nilai hasil belajar kognitif yang lebih tinggi dari pada ketiga belajar lainnya.

Siswa dengan gaya belajar converger memiliki nilai rata-rata hasil belajar kognitif tertinggi kedua, namun tidak memiliki perbedaan yang signifikan dengan gaya belajar accommodator. Gaya belajar converger merupakan kombinasi dari kutub kecenderungan abstract conceptualization (thinking) dan active experimentation (doing). Pada materi Pencemaran Lingkungan, siswa dengan gaya belajar converger lebih terfokus pada analisis logis dari situasi atau perkara yang dihadapi (Susilo, 2009). Siswa biasanya memiliki kemampuan yang baik dalam pemecahan masalah dan pengambilan keputusan. Dalam memecahkan masalah siswa mengerjakannya dengan pemikiran yang logis, sistematis, objektif, dan analisis. Hal tersebut sesuai dengan karakteristik materi Pencemaran Lingkungan yang mengedepankan daya analisis untuk memecahkan masalah.

Siswa dengan gaya belajar converger juga memiliki nilai rata-rata hasil belajar afektif tertinggi kedua, namun tidak berbeda signifikan dengan gaya belajar accommodator. Siswa dengan gaya belajar converger memiliki ciri khas cenderung tidak emosional (Ghufron dan Risnawita, 2012). Selain itu kutub kecenderungan active experimentation (doing) yang ada dalam diri siswa dengan gaya belajar converger, membuat siswa tersebut aktif selama proses pembelajaran, sama seperti siswa dengan gaya belajar accommodator. 
Selain itu siswa dengan gaya belajar converger juga memiliki nilai rata-rata hasil belajar psikomotorik tertinggi kedua, namun tidak berbeda signifikan dengan ketiga gaya belajar lainnya. Gaya belajar converger unggul dalam menemukan fungsi praktis dari berbagai ide dan teori. Selain itu, ciri khasnya lainnya adalah cenderung menyukai tugastugas teknis (aplikatif). Siswa dengan gaya belajar converger sangat prosedural, lebih suka bekerja dengan objek yang tidak bergerak dibandingkan dengan objek manusia (Indriana, 2011). Oleh karena itu, metode pembelajaran praktikum pada materi Pencemaran Lingkungan dapat dikatakan merupakan hal yang disukai oleh siswa dengan gaya belajar converger.

Berdasarkan data hasil belajar, dapat diketahui bahwa siswa dengan gaya belajar converger lebih unggul dalam hasil belajar ranah afektif. Hal tersebut dapat dilihat dari banyaknya jumlah siswa converger yang memiliki hasil belajar afektif yang berkriteria baik dan sangat baik. Namun secara teori, gaya belajar converger seharusnya unggul dalam hasil belajar psikomotorik karena ciri khasnya yang menyukai tugas-tugas aplikatif dan terampil dalam menemukan fungsi praktis dari sebuah teori. Selain itu gaya belajar converger juga unggul dalam hasil belajar kognitif karena kutub kecenderungan abstract conceptualization (thinking) membuat siswa converger berpikir secara objektif, runut, sistematis, dan melakukan pendekatan untuk pemecahan masalah dengan logika.

Siswa dengan gaya belajar assimilator memiliki nilai rata-rata hasil belajar kognitif di urutan ke tiga setelah gaya belajar accommodator dan converger, namun tidak memiliki perbedaan yang signifikan dengan kedua gaya belajar tersebut. Gaya belajar assimilator merupakan gabungan dari kutub kecenderungan reflective observation (watching) dan abstract conceptualization (thinking). Pada materi Pencemaran Lingkungan siswa dengan gaya belajar assimilator memiliki kelebihan dalam memahami berbagai sajian informasi yang dikumpulkan dari berbagai sumber. Informasi tersebut dipandang dari bebagai perspektif, dan dirangkum dalam sebuah format yang logis, singkat dan jelas (Ghufron dan Risnawita, 2012). Selain itu kutub kecenderungan abstract conceptualization (thinking) yang ada dalam diri siswa assimilator membuatnya memiliki daya analisis yang baik.

Siswa dengan gaya belajar assimilator juga memiliki nilai rata-rata hasil belajar afektif di urutan ke tiga setelah gaya belajar accommodator dan converger, namun tidak memiliki perbedaan yang signifikan dengan kedua gaya belajar tersebut. Kutub kecenderungan reflective observation (watching) yang ada dalam diri siswa dengan assimilator, membuat pendekatannya pada setiap situasi adalah mengamati dan bukan bertindak. Oleh karena itu siswa dengan gaya belajar assimilator pada umumnya lebih tenang dan pendiam. Selain itu siswa dengan gaya belajar assimilator suka mengamati perilaku orang lain (Nasution, 2009).

Siswa dengan gaya belajar assimilator memiliki rata-rata nilai hasil belajar psikomotorik yang paling rendah dan bebeda signifikan dengan gaya belajar accommodator. Gaya belajar assimilator lebih tertarik pada konsep-konsep abstrak dari pada aplikasi (Indriana, 2011). Siswa dengan gaya belajar assimilator cenderung lebih teoritis, mengasimilasikan fakta ke dalam teori, berpikir dengan objektif, analitis, melakukan pendekatan masalah dengan logika, dan berusaha benar-benar memahami sesuatu permasalahan terlebih dahulu sebelum melakukan tidakan (Ghufron dan Risnawita, 2012). Oleh karena itu siswa dengan tipe pemikir ini terlihat lebih pasif dalam melakukan kegiatan praktikum penjernihan air pada materi Pencemaran Lingkungan. 
Berdasarkan data hasil belajar, dapat diketahui bahwa siswa dengan gaya belajar assimilator lebih unggul dalam hasil belajar ranah afektif. Hal tersebut dapat dilihat dari banyaknya jumlah siswa assimilator yang memiliki hasil belajar afektif yang berkriteria baik dan sangat baik. Namun secara teori, gaya belajar assimilator juga unggul dalam hasil belajar kognitif karena ciri khasnya yang suka mengintegrasikan hasil amatannya ke dalam sebuah teori dan cenderung berpikir secara analitis, runut, dan sistematis.

Siswa dengan gaya belajar diverger memiliki rata-rata nilai hasil belajar kognitif yang paling rendah dan bebeda signifikan dengan gaya belajar accommodator dan converger. Gaya belajar diverger merupakan gabungan dari kutub kecenderungan concrete experience (feeling) dan reflective observatioan (watching). Siswa dengan gaya belajar diverger unggul dalam melihat situsi kongkret dari berbagai sudut pandang yang berbeda. Selain itu kekuatan gaya belajar diverger terletak pada kemampuan imajinasinya (Nasution, 2009). Mata pelajaran Biologi khususnya pada materi Pencemaran Lingkungan tidak mengedepankan imajinasi dalam proses pemecahan masalah. Disamping itu gaya belajar ini memiliki kelemahan yaitu cepat bosan jika persoalan membutuhkan waktu yang lama untuk dapat dipahami, dipecahkan atau diselesaikan (Ghufron dan Risnawita, 2012). Hal tersebut yang mungkin menyebabkan siswa dengan gaya belajar diverger memiliki nilai rata-rata hasil belajar kognitif yang lebih rendah dibandingkan dengan ketiga gaya belajar lainnya.

Siswa dengan gaya belajar diverger juga memiliki rata-rata nilai hasil belajar afektif yang paling rendah dan bebeda signifikan dengan gaya belajar accommodator dan converger. Kutub kecenderungan reflective observation (watching) yang ada dalam diri siswa diverger membuat siswa tersebut melakukan pendekatan pada setiap situasi dengan mengamati dan bukan bertindak. Kecenderungan reflective observation (watching) membuat siswa diverger lebih pasif saat pembelajaran. Selain itu ciri khas gaya belajar diverger yang cepat bosan, yang mungkin membuat siswa diverger melakukan hal-hal lain di luar pelajaran sehingga mengakibatkan rendahnya hasil belajar afektif.

Siswa dengan gaya belajar diverger lebih unggul dalam hasil belajar psikomotorik, dibandingkan kognitif dan afektif. Hal tersebut dapat dilihat dari banyaknya jumlah siswa diverger yang memiliki nilai hasil belajar psikomotorik yang berkriteria baik dan sangat baik. Siswa dengan gaya belajar diverger memiliki nilai rata-rata hasil belajar psikomotorik tertinggi ketiga, namun tidak berbeda signifikan dengan ketiga gaya belajar lainnya. Gaya belajar diverger unggul dalam melihat situasi kongkret dari banyak sudut pandang berbeda. Siswa dengan gaya belajar diverger biasanya ingin mengalami suatu pengalaman dan tidak takut untuk mencoba (Ghufron dan Risnawita, 2012). Metode praktikum merupakan sebuah pengalaman kongkret bagi siswa dengan gaya belajar diverger. Namun seringkali pendekatan yang dilakukan siswa diverger dalam berbagai situasi adalah mengamati dan bukan bertindak (Susilo, 2009).

Penelitian tentang gaya belajar David Kolb juga telah dilakukan oleh Othman (2004). Penelitian tersebut menyatakan gaya belajar yang paling banyak dimiliki oleh mahasiswa jurusan Biologi di Fakultas Pendidikan, Universitas Kebangsaan Malaysia adalah gaya belajar converger (31.66\%), kemudan dilanjutkan oleh accommodator $(26,67 \%)$, diverger (21,67\%), dan terakhir assimilator (20\%). Hal tersebut sedikit berbeda dengan hasil penelitian ini dimana gaya belajar accommodator yang lebih dominan dalam pembelajaran Biologi. Namun pada penelitian ini dapat diketahui bahwa hasil belajar siswa dengan gaya 
belajar converger tidak berbeda signifikan dengan gaya belajar accommodator baik dalam ranah kognitif, afektif, dan psikomotorik.

\section{KESIMPULAN}

Berdasarkan hasil penelitian dan pembahasan dapat disimpulkan bahwa terdapat pengaruh gaya belajar David Kolb (diverger, assimilator, converger, accommodator) terhadap hasil belajar siswa pada materi Pencemaran Lingkungan.

\section{DAFTAR PUSTAKA}

Cassidy, S. (2004). Learning Style : An Overview and Measures. Educational Psychology, 24(4), $419-444$.

Claxton, C. S. dan P. H. Murrell. (1987). Learning Style : Implication for Improving Educational Practices. Washington DC : Association for the Study of Higher Education.

Ghufron, M. N. dan Rini Risnawita. (2012). Gaya Belajar: Kajian Teoritik. Yogyakarta: Pustaka Pelajar.

Indriana, Dina. (2011). Mengenal Ragam Gaya Pembelajaran Efektif. Yogyakarta : DIVA Press.

Othman, Norasmah dan Siti R. Othman. (2004). Gaya Pembelajaran Kolb dalam Mata Pelajaran Biologi. Jurnal Teknologi, 40(E), 45 - 58.

Nasution, S. (2009). Berbagai Pendekatan dalam Proses Belajar dan Mengajar. Jakarta : Bumi Aksara.

Ramlah, Firmansyah, Dani, dan Zubair, Hamzah. (2014). Pengaruh Gaya Belajar dan Keaktifan Siswa terhadap Prestasi Belajar Matematika (Survei pada SMP Negeri di Kecamatan Klari Kabupaten Karawang. Jurnal Ilmiah Solusi,1(3), 68 -75.

Slameto. (2003). Belajar dan Faktor-faktor yang Mempengaruhi. Jakarta : Rhineka Cipta.

Sugiyanto. (2007). Kontribusi Gaya Belajar dan Motivasi Berprestasi terhadap Prestasi Akademik Siswa Kelas XI SMA Negeri 10 Semarang. http://staff.uny.ac.id/ sites/default/ files/132319838/artikel\%20makalah.pdf, diunduh 10 Januari 2015 pukul 20.00.

Susilo, M. Joko. (2009). Sukses dengan Gaya Belajar. Yogyakarta : Pinus Book Publisher.

Wijayanti, Sri. (2011). Perbandingan Hasil Belajar Biologi Berdasarkan Ragam Gaya Belajar Menurut Kolb pada Pembelajaran dengan Metode Praktikum. Skripsi. Jakarta : Universitas Negeri Jakarta 